\title{
PSYCHOSOCIAL PREDICTORS OF THE CHANGING ROLE OF HUSBANDS AS BREADWINNERS IN A DEPRESSED ECONOMY IN IBADAN METROPOLIS, OYO STATE, NIGERIA
}

\author{
Ezeani Paschal Tochukwu ${ }^{1}$ and Sabboh Godwin Matthew ${ }^{2}$ \\ ${ }^{1}$ Department of Counselling and Human Development Studies, Faculty of Education, \\ University of Ibadan. Email: pat4uinsdv@ gmail.com \\ ${ }^{2}$ National Research University, Higher School of E, Moscow, Russia. \\ Email: gsabbokh@edu.hse.ru
}

Cite this article:

Ezeani P.T., Sabboh G.M. (2021), Psychosocial Predictors of the Changing Role of Husbands as Breadwinners in a Depressed Economy in Ibadan Metropolis, Oyo State, Nigeria. British Journal of Education, Learning and Development Psychology 4(2), 31-42. DOI: 10.52589/BJELDPZU3KSUJU.

\section{Manuscript History}

Received: 30 Sept 2021

Accepted: 19 Oct 2021

Published: 30 Oct 2021

Copyright $\odot 2020$ The Author(s). This is an Open Access article distributed under the terms of Creative Commons Attribution-NonCommercialNoDerivatives 4.0 International (CC BY-NC-ND 4.0), which permits anyone to share, use, reproduce and redistribute in any medium, provided the original author and source are credited.
ABSTRACT: Changing roles of husbands as breadwinners among couples, particularly in a poor economy, has been a source of concern for most Nigerian families, resulting in many homes being broken (divorced and separated) and even children begging for alms on the streets. Despite the extensive literature on the effects of marital conflicts, parenting styles, and economic constraints on marital stability, few studies on how these factors interact to affect husbands' evolving status as breadwinners. This study, therefore, examined the psychological predictors (marital disagreement, parenting style and economic challenge) of the changing role of husbands as breadwinners in a depressed economy in the Ibadan metropolis of Oyo State, Nigeria. Marital communication and structural theories provided the framework, while the descriptive survey design was adopted. Three Local Government Areas (LGA) - Ibadan South-west, Ibadan North-west, and Ibadan North - were selected out of the nine LGA using stratified random sampling. Three hundred participants from (3 Churches 213, 2 Markets 81, and 1 School 6) were carefully chosen through a convenience sampling technique. The instruments used were changing role $r=.79$, marital disagreement $r=.90$, parenting style $r=$ .89 scales. Data were analysed using Pearson Product Moment Correlation and Multiple Regression Analysis at a 0.05 level of significance. The finding revealed that there were significant positive relationships between marital disagreement $r=.487, p<0.05$, and economic challenge $r=.249, p<0.05$ on changing roles while there was no relationship between parenting style $r=-.089, p>0.05$ on changing roles. The three independent variables jointly accounted for $31.1 \%$ variance in predicting change in roles of the husband as breadwinner. The independent variables made a positive relative contribution to change in role in the following order: marital disagreement $(\beta=-0.117, t=-2.407$, $p<0.05$, which had a relative contribution to changing role of husbands from breadwinner among couples in Ibadan metropolis. Specific roles and responsibilities should not be overemphasised among couples, rather the emphasis should be on improvements, achievements, and successes recorded together as husbands and wives, and not as individual people. This will reduce the increasing attitude toward self-oriented goals instead of "the family achievements."

KEYWORDS: Marital Disagreement, Parenting style and Economic Challenge, Changing role, Breadwinner 


\section{INTRODUCTION}

Whether role or responsibility, husband and wife have a well-defined duty that they each should discharge in the family, whether these responsibilities or roles are imposed on them by the society, or whether they are culturally based may not be ascertained. But then, the Holy books, Quran and Bible are very clear about the unique responsibilities that God assigned to both the husband and the wife. The role of the husband in the Bible, for instance, include leadership (1 Timothy 3; 1 Cor. 11:3), provider and protector (1 Timothy 5:8; Colossian 3:19; 1 Peter 3:7), Companion (Eph. 5:25-33). However, the last century witnessed a virtual revolution that occurred in gender relations, beginning in Western European countries and North America between World War 1 and World War 11, which continue spreading, although unevenly, to the developing countries of Asia, Africa, Latin America, and America. The subsequent decline in family values has become necessary in redefining the roles of men and women and the notion of the ideal family. The seeming uproar and battle by women all over the world to rise to the top position in politics and other spheres of life influenced most Nigerian women who are also taking over the leadership of homes. The fact that there are so many of them attests to this, women who are now the breadwinners against the order of God and nature. As society evolves, the role of family and gender becomes dinner and blurry. Be that as it may, the traditional role of a woman as caretaker of the home front and the man as breadwinner is no longer stereotyped. The man as head of the family is expected to lead, provide for, and protect his family.

For instance, in the erring economy of Nigeria, most men are incapacitated financially to take care of the family. Thus, women are expected to contribute financially and aid in catering for the family. These new trends and patterns have resulted in changes in roles, particularly the growth of the female role to include financial provision for a family and, more recently, the modification of the male role to include more responsibility. Intensive involvement in family responsibilities, especially the care for children and some home chores. However, these changes have led to more and more complex family composition and to a growing diversity of family forms and relationships over the life course. In other words, work and family lives are increasingly influencing one another, as both men and women engage in earning and caring activities, which is sometimes exacerbated by job insecurity and precariousness. These unusual roles emerged due to several psychosocial variables, which include: unstable economy, more female participation in education, marital disagreement, parenting style and employment opportunities that are more open to women in recent times. The marital disagreement could be caused by so many factors like poor communication, lack of understanding, intolerance, unforgiveness, and many more. From every indication, marital disagreement will bring about a negative response to a change in the role of either of the couple. Couples who disagree find it difficult to accept and respect each other and talk more when there is a change in role/responsibility.

The family background of most couples largely influences them on accepting their roles as husbands or as wives. Simply because the woman grew up in a home where the father was jobless and the mother provides for the home. Due to the unemployment, her understanding father consistently continues to handle most of the home chores, now that she is married, both she and the husband are working. Similarly, unemployment is another factor that influences the traditional roles of men as leaders, protectors, and providers (breadwinners) of the home. Consciously or unconsciously, most men struggle to be the leaders of their families; they make frantic efforts to protect and provide for their families' needs. But then, when they lack the means of achieving this goal due to unemployment, the women take over. This is why when 
men become "redundant", the stage is set for family conflict where there is a lack of understanding.

In nearly all human societies, therefore, the role of husbands in providing for the needs of their family members cannot be overstressed. It has been evident that whether in primitive or contemporary societies, a man's role from a tender age had been defined by the society in a way that providing food for the wife and children is an obligation. Their roles include serving as providers and the conveyors of moral values and religious education to their children (Odumaike 2012). In other words, the central role of a man was to serve as the major provider for his family irrespective of his wife's status. Most African countries for instance considered that a wife's feeding of her husband was unusual. Thus, a woman who tries to mix men's roles with her conventional roles as housekeeper and nurturer of children is quickly reminded that she is defying social conventions. The attributes associated with being a wife and mother (nurturance, emotionality, and attention to people rather than ideas) are considered incompatible with those associated with professional success (independence, logic, and creativity) (leadership, and assertiveness) (Mead, 2008; Eboiyehi 2013). So, if women have always been assigned the traditional role of the family caretaker and not of breadwinner, how would the family survive and be sustained especially in this erring economy of Nigeria where men are almost incapacitated?

\section{Statement of the problem}

The traditional role of a woman as caretaker of the home front and the man as breadwinner is no longer stereotyped where the man is head of the family (expected to lead, provide for, and protect his family), which has been a God-given role since creation; but because agriculture is no longer the main source of income for many families, women are for obvious reasons are expected to contribute financially and in some situation, becomes the breadwinner, if not the sole provider in the home. Should marriages collapse or allow to suffer because several factors prevent their husbands from playing their traditional roles as head of the family? Ideal marriage between a man and a woman is a complementarity. This is expressed in mutual love, mutual respect, mutual support, and mutual responsibility. By implication, what each have, earn or own belongs to the two, and this should be collectively used for the family's welfare. Thus, in as much as it is the "primary role" of the husband to lead, provide, and protect the family. Would it then be out of place for the wife to support, complement and improvise when the husband is not capable? The issue of parenting is a co-responsibility of both husband and wife because there is always agreement, understanding, and consent before, during and after major decisions of the family is decided. The fuss, conflict, misunderstanding and instabilities in marriages arise when there is neglect, lack of communication, marital disagreement, influence from poor family background or parenting style. Therefore, this study examines the effects of these psychosocial predictors of the changing role of husbands in Ibadan Metropolis as breadwinners, especially in the erring economy.

\section{Purpose of the Study}

The general purpose and objective of this study is to examine psychosocial predictors of the changing role of husbands in Ibadan Metropolis. To guide the study, the following specific goals were: 
1. To examine the relationship between the independent factors (economic challenges, parenting style and marital disagreement) on the changing role of husbands in Ibadan Metropolis as the breadwinner in the erring economy.

2. To investigate the joint contribution of the independent factors (economic challenges, parenting style and marital disagreement) on the changing role of husbands in Ibadan Metropolis as the breadwinner in the erring economy.

3. To examine the relative contribution of the independent variables (marital disagreement, economic challenges, employment opportunities and parenting style) on the changing role of husbands in Ibadan Metropolis as breadwinners.

\section{Research questions}

1. What relationship pattern exists between the independent variables (economic challenges, parenting styles and marital disagreement) on changing the role of husband from breadwinner among couples in Ibadan Metropolis of Oyo state?

2. To what extent will economic challenges, parenting styles and marital disagreement when combined correlates the changing role of husband from breadwinner among couples in Ibadan Metropolis of Oyo state?

3. To what extent will each variable (economic challenges, parenting styles and marital disagreement) correlate the changing role of husband from breadwinner among couples in Ibadan Metropolis of Oyo state?

\section{REVIEW OF RELATED LITERATURE}

Historically, women have always been assigned the traditional role of the family caretaker (Marecek and Ballou, 2011); however, the new norm of the traditional family has both spouses working outside the home and a decrease in the wage gap between spouses (Crompton and Geran, 2005). More so, there is a growing proportion of working couples in which the wife earns more than the husband to become the female breadwinner. Meisenbach (2010) asserts that many of these women felt enormous guilt and resentment. Stanley and Einhorn (2009) found that one of the reasons for economic challenges is that financial transactions and payment obligations are common events, which may be linked more strongly to negative conflict tactics. Couples will have many opportunities to dispute about anything that will affect their lives due to this. Bills, for example, arrive on a monthly - if not weekly - basis, and normal expenditures, such as food and fuel, must be made regularly. Large unanticipated costs, such as car repairs, can also occur. For example, Villanova and Bownas (2014) found that economic challenges could help couples cope with everyday life stressors and lighten the burden of changing the role of the husband. Without enough support from the wife, the children and husband would be less trouble and less vulnerable to life stress. Denga (2002) reveals in his work that marital disagreement makes couples emotionally unstable and psychologically imbalanced and enhances the changing role of husband from breadwinner acts. Osarenren (2006) also asserted that marital disagreement from couples may make their marriage to be less accomplished due to their changing role acts. In conclusion, this poor expectation from couples influences their ability to check their children at home, which certainly has some negative effect on the 
changing role of either the husband or the wife because they do not trust and understand each other.

Vella, Persic, and Lester (2016) did a study that explored whether self-reported parenting styles was associated with the changing role of husband after controls for the economic recession were introduced. The Beck Depression inventory scale was given to 131 couples. These researchers found that changing the role of the husband was negatively correlated with parenting styles. As parenting styles declined, changing role of the husband increased among the couples' population. Economic challenges were found to be one of the most important protective factors for wives to control the house and turn their husbands into wives due to their financial incapability (Tao, Dong, Pratt, Hunsberger and Pancer, 2010). Dori and Overholser (1999) also found that parenting styles are good indicators of the changing role of the husband from the breadwinner. Dori and Overholser (1999) did a study to determine whether the level of parenting styles was different among the changing role of the husband. They recruited 90 married couples diagnosed with permissive and authoritarian parenting styles. These married couples ranged from 33 to 59 years old, and they were in the middle socioeconomic category. Those who attempted changing the role of the husband had significantly lower permissive parenting styles and higher levels of acceptance and trust in each other than their higher level of authoritarian parenting styles counterparts, as assessed by Dori and Overholser (1999). Parenting styles were also found to be a better indicator of the changing role of the husband than a couple's level in their study.

Furthermore, a negative correlation between marital disagreement and changing role of the husband has been reported by Weissman and Eastland (2004) in that high turnout of marital disagreement have been associated with a high level of a changing role of the husband in couples of today. Marital disagreement was one of the most important negative factors for couples changing roles (Lung, Xing, Pat, and Paul, 2010). A study by Wentzel (1998) found that economic challenges provide un-motivational influence on couples toward the changing role of the husband from the breadwinner.

\section{Theoretical framework}

The marital communication theory

The marital communication theory was propounded by Weakland (1956). According to him, conflict in marriage is due to inappropriate communication. The theory stipulates that conflict ensues in marital relationships in a situation where there is confusion and lack of clarity in the communication pattern of husband and wife. This is a situation when the partner who is receiving the message of the communication finds it very difficult to make meaning out of the communication. According to the theory, there are three levels in human communication where conflict can arise. Such levels are at the syntactic, semantic, and pragmatic levels in communication networks. The syntactical story concerns the manner in which information is conveyed; the semantic level concerns when the recipient receives the information; and the pragmatic level concerns the impact of the information on each other. According to the marital communication theory paradigm, issues emerge in marriage when partners fail to interpret information communicated by one other clearly. 


\section{The Structural Theory}

The structural theory was postulated by Minuchin (1974). According to the theory, marital conflict arises where the personality of one of the parties in marriage swallows the personality of the other. It can result also in a situation where one's interest clashes with the interest of others. It can equally be in a situation where the couple's approach to marital problems is immature. This theory stipulates that conflicts arise when the couple finds it difficult to interact positively in their relationship by allowing significant others, like in-laws, business associates, colleagues at the office, friends, and neighbours to influence the relationship in their marriage. By its definition "structural", the husband who is the breadwinner will not be pleased to see the status quo change in whatever circumstance. This means that in the change of role of either of the spouses, there will always be disagreement or quarrel.

\section{METHODOLOGY}

The design for the study is a descriptive survey research design using the ex-post facto. Expost facto research design, according to Nwagu (2005) is a systematic empirical inquiry in which the researcher does not have direct control on independent variables because they are inherently not easy to manipulate. The target population comprised all married adults in Ibadan Metropolis of Oyo State. The purpose of selecting this study locale is because Ibadan is a metropolitan city and as such will provide the opportunity to study a heterogeneous population within this environment. The sample for the study was drawn from the target population using the purposive sampling technique. Stratified random sampling was also used to select three local government areas out of the nine within the Ibadan metropolis. Two churches, St. Gabriel Catholic Church, Mokola (45 respondents), Ikolaba Grammar school (6 respondents) and Ascension Catholic Church, Bodija (76 respondents) were selected from Ibadan North Local Government, while Dugbe market (25 respondents) were selected from Ibadan North West and St. Joseph Catholic Church, Oke-Ado (92 respondents) and Aleshinloye market (56 respondents) were selected from Ibadan South West Local Government Area. The researcher visited markets, schools, and churches within the study areas. The justification for selecting this sampling technique for this study was because of the easy accessibility of the researcher to reach the target population.

A questionnaire was used as an instrument for data collection. The questionnaire was structured into four sections. Section A examined the socio-demographic characteristics including sex, tribe, religion and length of the marriage. Section B measures the changing role scale which consisted of 20 items. Section C elicits information on the marital disengagement scale which comprised 16 items. Section D elicits information on the economic Challenge and it consisted of 15 items. While section E elicits information on parenting styles and it consisted of 10 items. The content and face validation of the questionnaire was done by giving it to two experts in the field of test and measurement, University of Ibadan. The comments and corrections suggested were effected and in ensuring the reliability of the questionnaire, a pilot study was conducted. The questionnaire was administered on 30 married individuals in Akinyele Local Government Area of Oyo State and the Cronbach Alpha reliability coefficients were reported as follows: changing roles scale $(\alpha=0.89)$, marital disengagement $(\alpha=0.81)$, economic Challenge $(\alpha=$ $0.84)$ and parenting styles $(\alpha=0.82)$. Three hundred responses were got from the respondents which were later used for the data analysis. The data was analysed using descriptive and 
British Journal of Education, Learning and Development Psychology

ISSN: 2682-6704

Volume 4, Issue 2, 2021 (pp. 31-42)

www.abjournals.org

inferential statistics. The research questions were analysed using inferential statistics of Pearson's product-moment correlation and regression with the aid of the Statistical Package for Social Science (SPSS, 21) at a 0.05 level of significance.

\section{RESULTS}

Table 1: Demographic characteristics of the respondents

\begin{tabular}{|l|l|c|l|}
\hline Demographic Characteristics & Frequency & Percentage \\
\hline Gender & Male & 155 & 51.7 \\
& Female & 145 & 48.3 \\
\hline Tribe & Yoruba & 115 & 38.3 \\
& Igbo & 120 & 40.0 \\
& Hausa & 52 & 17.3 \\
& Others & 13 & 4.3 \\
\hline Religion & Christianity & 197 & 65.7 \\
& Islam & 87 & 29.0 \\
& Traditional & 7 & 2.3 \\
& Others & 9 & 3.0 \\
\hline Years in marriage & 1-20 years & 178 & 59.3 \\
& $11-20$ years & 97 & 32.3 \\
& 21 years and above & 25 & 8.3 \\
\hline
\end{tabular}

The result from Table 1 shows that out of 300 respondents who partook in the study, 155 $(51.7 \%)$ were males and the remaining $145(48.3 \%)$ were females. This implies that both males and females were fully represented but males were potently represented in the study. It is attested that $115(38.3 \%)$ were Yoruba, $120(4.0 \%)$ were Igbo, while $52(17.3 \%)$ were Hausa and the rest $13(4.3 \%)$ did not belong to any of the three tribes. This means that the three tribes were fully represented but the Igbos were more represented in the study. Result also shows that 197 (65.7\%) were Christians, 87 (29.0\%) were Muslims while 7 (2.3\%) were Traditionalists and the rest, $9(3.0 \%)$, did not belong to any of the three religions. This means that more Christians participated more in the study than their other counterparts. Also, respondents whose years of marriage fell between 1-20 years were 178 (59.3\%) while 97 (32.3\%) fell between 1120 years and the rest $25(8.3 \%)$ fell between 21 and above. This means that respondents whose years of marriage fell between 1-20 years were fully represented in the study. 
British Journal of Education, Learning and Development Psychology

ISSN: 2682-6704

Volume 4, Issue 2, 2021 (pp. 31-42)

www.abjournals.org

\section{Answering research questions}

Research question 1: What pattern of relationship exists between the independent variables (economic challenges, parenting styles and marital disagreement) on the changing roles of the husband from breadwinner among couples in Ibadan Metropolis of Oyo state?

Table 2: Correlation matrix showing the relationship between the independent variables on the dependent variable

\begin{tabular}{|l|r|r|r|l|l|l|}
\hline Variables & \multicolumn{1}{|l|}{ Mean } & Std. Dev & \multicolumn{1}{l|}{} & $\mathbf{2}$ & $\mathbf{3}$ & $\mathbf{4}$ \\
\hline Changing roles & 47.5000 & 8.1682 & 1 & - & - & - \\
\hline Marital Disagreement & 35.4100 & 6.7320 & $.487^{* *}$ & 1 & - & - \\
\hline Economic Challenge & 63.5500 & 12.7098 & $.334^{* *}$ & $.161^{* *}$ & 1 & - \\
\hline Parenting Style & 60.6767 & 10.9186 & -.089 & .108 & -.089 & 1 \\
\hline
\end{tabular}

Table 2 reveals the inter-correlation matrix of the significant relationship among the independent variables to the changing role of husband from breadwinner among couples in Ibadan Metropolis. The result shows a positive significant relationship among the independent variables to changing roles except for parenting style that didn't show any significant relationship. Marital disagreement $(\mathrm{r}=.487 * * \mathrm{~N}=300, \mathrm{P}<.05)$, economic challenge; $(\mathrm{r}=$ $\left..334^{* *}, \mathrm{~N}=300, \mathrm{P}<.05\right)$ and parenting style; $(\mathrm{r}=-.089, \mathrm{~N}=300, \mathrm{P}>.05)$. This indicates out of the three independent variables, marital disagreement and economic challenge are indicators of the changing roles of the husband while parenting style is not an indicator.

Research question 2: To what extent will economic challenges, parenting styles and marital disagreement when combined correlates the changing role of husband from breadwinner among couples in Ibadan Metropolis of Oyo state?

Table 3: Joint contribution of economic challenges, parenting styles and marital disagreement on changing role

\begin{tabular}{|c|c|c|c|c|c|c|}
\hline $\mathbf{R}$ & \multicolumn{3}{|l|}{ R Square } & $\begin{array}{c}\text { Adjusted R } \\
\text { Square }\end{array}$ & \multicolumn{2}{|c|}{$\begin{array}{l}\text { Std. Error of the } \\
\text { Estimate }\end{array}$} \\
\hline $.563^{\mathrm{a}}$ & & & .317 & .311 & & 6.78239 \\
\hline \multicolumn{7}{|l|}{ A $\mathrm{NOVA}$} \\
\hline Model & $\begin{array}{l}\text { Sum of } \\
\text { Squares }\end{array}$ & DF & $\begin{array}{l}\text { Mean } \\
\text { Square }\end{array}$ & $\mathrm{F}$ & Sig. & Remark \\
\hline $\begin{array}{l}\text { Regression } \\
\text { Residual } \\
\text { Total }\end{array}$ & $\begin{array}{l}6332.765 \\
13616.235 \\
19949.000\end{array}$ & $\begin{array}{l}3 \\
296 \\
299\end{array}$ & $\begin{array}{l}2110.922 \\
46.001\end{array}$ & 45.889 & .000 & Sig. \\
\hline
\end{tabular}

Table 3 reveals the significant joint contribution of the independent variables (economic challenges, parenting styles and marital disagreement) to the prediction of the changing role of the husband. The result yielded a coefficient of multiple regressions $\mathrm{R}=0.563$ and multiple $\mathrm{R}$ square $=0.311$. This suggests that the three factors combined accounted for $31.1 \%$ (Adj. $\mathrm{R}^{2}=$ .0 .311 ) variance in the prediction of changing role. The other factors accounting for the 
remaining variance are beyond the scope of this study. The result from the regression analysis shows that there was a significant effect of the independent variables on the changing role of husband as the breadwinner, $\mathrm{F}_{(3,296)}=45.889, \mathrm{P}<0.05$

Research question 3: To what extent will each of the variables (economic challenges, parenting styles and marital disagreement) correlate to the changing role of the husband from breadwinner among couples in Ibadan Metropolis of Oyo State.

Table 4: Relative contribution of each of the independent variables to the prediction of the changing role of the husband from breadwinner

\begin{tabular}{|c|c|c|c|c|c|c|}
\hline \multirow{2}{*}{\multicolumn{2}{|c|}{ Model }} & \multicolumn{2}{|c|}{$\begin{array}{l}\text { Unstandardised } \\
\text { Coefficients }\end{array}$} & \multirow{2}{*}{$\begin{array}{c}\begin{array}{c}\text { Standardised } \\
\text { Coefficients }\end{array} \\
\text { Beta } \\
\end{array}$} & \multirow[t]{2}{*}{$\mathbf{T}$} & \multirow[t]{2}{*}{ Sig. } \\
\hline & & B & Std. Error & & & \\
\hline \multirow{4}{*}{1} & (Constant) & 22.880 & 3.435 & & 6.661 & .000 \\
\hline & $\begin{array}{l}\text { Marital } \\
\text { Disagreement }\end{array}$ & .558 & .059 & .460 & 9.372 & .000 \\
\hline & \begin{tabular}{|l} 
Economic \\
Challenges \\
\end{tabular} & .160 & .031 & .249 & 5.095 & .000 \\
\hline & Parenting Style & -.087 & .036 & -.117 & -2.407 & .017 \\
\hline
\end{tabular}

Table 4 above shows the relative contribution of the independent variables to the prediction of the changing role of the husband among couples in Ibadan Metropolis. In terms of the magnitude of the contribution: Marital disagreement and economic challenge contributed more to the prediction of changing role of the husband among couples in Ibadan Metropolis. Marital disagreement $(\beta=0.460, \mathrm{t}=9.372, \mathrm{P}<.05)$, economic challenge $(\beta=0.249, \mathrm{t}=5.095, \mathrm{P}<.05)$ and parenting style $(\beta=-0.117, \mathrm{t}=-2.407, \mathrm{P}<0.05$ had relative contribution to changing role of husband among couples in Ibadan Metropolis. This implies that each of these independent variables is a compelling factor in the changing role of the husband.

\section{DISCUSSION}

The result from research question one showed that there was a significant relationship between economic challenges and changes in the role and also between marital disagreement and changes in the role while parenting style and changes in the role did not show any relationship. On the relationship between economic challenges and changing roles, the finding of this study corroborates Stanley and Einhorn, (2009) who found that one of the reasons economic challenges may be related more strongly to negative conflict tactics is that financial transactions and payment obligations are frequent events. The findings also go in line with that of Villanova and Bownas (2014) who found that economic challenges could help couples to cope with everyday life stressors and lighten the burden of changing the role of a husband. On the relationship between marital disagreement and changing the role, the finding corroborates Denga (2012), who concluded in his work that marital disagreement makes couples to be emotionally unstable and psychologically imbalanced and it enhances changing the role of the husband from breadwinner acts. Parenting style was not significantly correlated with changing the role which corroborates Vella, Persic and Lester (2016) who found that a self-reported 
parenting style was associated with changing the role of the husband after controls for the economic recession were introduced. These researchers found that changing the role of the husband was negatively correlated with parenting styles.

Results from research question two revealed that there was a significant joint contribution of the independent variables (marital disagreement, economic challenges, and parenting styles) to the changing role. Marital disagreement contributed to the prediction of changing roles which corroborates Osarenren (2006) who found that marital disagreement from couples making their marriage less fulfilled with their changing of the role of husband from breadwinner acts. This poor expectation from couples or busy to check their children at home have some negative effect on the changing role of husband and they will high fulfilment in marital disagreement acts because they do not trust and understand each other at all. And the joint contribution of an economic challenge to changing role is also consistent with the finding of Tao, Dong, Pratt, Hunsberger and Pancer, (2010) who found that economic challenges were one of the most important protective factors for wives to control house and turn her husband to wife due to his financial incapability. And much earlier findings from Dori and Overholser (2009), who found that parenting styles are a good indicator of the changing role of the husband from the breadwinner. This means that the three independent factors when taken together predicted the changing role of the husband as breadwinner.

The result from research question three showed that each independent variable contributes to the prevalence of the changing role of the husband as breadwinner among married men in Ibadan Metropolis. Sequel to the fact above, their contribution is positive. On the part of relative contribution of marital disagreement to changing roles of husbands, the finding corroborates Lung, Xing, Pat and Paul (2010), who concluded that marital disagreement was one of the most important negative factors for couples changing role of the husband. The finding also lends credence with that of Wentzel (2008), who found that economic challenges provide un-motivational influence on couples toward the changing role of the husband from the breadwinner. Much earlier findings from Dori and Overholser, (2009) reported that parenting styles also was a better indicator of the changing role of the husband than a couple's level in their study.

\section{CONCLUSION AND RECOMMENDATIONS}

This study has provided more details to the existing information on the changing role of husbands as a factor that required immediate solution. From this study, it becomes clear that various measures should be put in place by husbands and wives to curb the excesses that could hinder the changing role of husbands from being the breadwinner of the family. It could be concluded that the type of job husbands' do should also be considered when appraising their changing roles that is hindering them from becoming the breadwinner of the family. It is therefore recommended that:

1. Specific roles and responsibilities should not be emphasised among couples, rather the emphasis should be on improvements, achievements, and successes recorded together as husbands and wives, and not as a person. This will reduce the increasing attitude toward self-oriented goals instead of "the family." 
2. Intending couples should understand each other better before they get married, this would give room for better ways of handling issues when they get married to avoid unnecessary disagreement, or misunderstanding, which could jeopardise their marital relationship.

3. Intending couples should be exposed to the course Economics of Marriage. This will expose them to the economic reality of marriage, which include planning together, spending together, and managing together. These acts will reduce the traditional belief that men should provide for every need of the family. It will also increase the awareness of unitary parenting and home management.

4. Wives should understand that they have the obligation to support their husbands financially and even morally as long as they have the means. This may reduce the danger poses by economic challenges that could affect the role of their husbands as breadwinners.

5. Husbands should also learn how to save for rainy days in that the economy of the country is not stable and when the economy is not buoyant, husbands could go back to their savings to enable them to cater for the needs of their families.

\section{REFERENCES}

Crompton, R, \& Geran, C. (1995). Depression and marital functioning: An examination of specificity and gender differences. Journal of Abnormal Psychology, 98, 23-30.

Denga, A, (2012). Exposure to interparental conflict and psychological disorder among young adults. Journal of Family Issues, 27, 131-158.

Dori, V, \& Overholser, P. (2009). Family discord and stress predictors of depression and other disorders in adolescent children of depressed and nondepressed women. Journal of the American Academy of Child and Adolescent Psychiatry, 43, 994-1002.

Eboiyehi, C. (2013). Changing Triyes, Marriage, Divorce, Remarriage. Counseling Today's Families. Califonia: Brools / Cole Publishing Company, Pacific Grove.

Hetherington, D., \& Stanley, J.D (2002) Variation in socioeconomic gradients among cantons in French and Italian-speaking Switzerland: Findings from the OECD PISA.

Educational Research and Evaluation, 12(2), 129-154.

Lung, P., Xing, K. G., Pat, V., \& Paul, N. (2010). 'Punishment enhances reasoning's effectiveness as a disciplinary response to toddlers', Journal of Marriage and the Family, Vol. 60, pp. 388-403.

Marecek, B, \& Ballou, V (2008). Interparental conflict and the children of discord and divorce. Psychological Bulletin, 92, 310-330

Mead, G. B. (2008). Constructing Breadwinning-Mother Identities. Moral, Personal and political Positioning. Women's Studies Quarterly, 37(3/4), 140-156.

Meisenbach, F. (2010). Family discord and stress predictors of depression and other disorders in adolescent children of depressed and nondepressed women. Journal of the American Academy of Child and Adolescent Psychiatry, 43, 994-1002.

Minuchin, F. (1974) Physical Violence by Husbands: magnitude, Disclosure, and Help Seeking Behavior of Women in Bangladesh.” Social Science and Medicine 62:29172929. 
Odumaike, A. (2012). Adjustment Strategies of Divorcees in some selected communities of Enugu State. Unpublished Ph.D Thesis. Department of Education, University Of Nigeria, Nsukka.

Osarenren, R. (2006). Demographic correlates of marital problems among couples in Enugu State. Unpublished Ph.D Thesis. Department of Educational Foundations, University of Nigeria, Nsukka.

Stanley, E., \& Einhorn, A. (2009). Family support, coping, and competence. In E.M.Tao, F, Dong, S, Pratt, Y. Hunsberger. S, \& Pancer, U. (2010) A. study of marital enrichment programs and couple's quality of life. Journal of Psychology and Theology, 31, 3, 240252.

Vella, F, Persic, T and Lester, S. (2016). Family support and conflict: Prospective relations to adolescent depression. Journal of Abnormal Child Psychology, 25, 333-344.

Villanova, E., and Bownas, D. (2014). Divorce as Bifurcation: Redefining a Nuclear System (Master's thesis). University of South Africa.

Weakland, M.N (1956) Divorce: its cause and impact on the lives of divorced women and their children: A comparative study between divorced and intact families (Master's thesis). Addis Ababa University.

Wentzel, D. (2008). Parenting Competence'. In: M.H. Bornstein (ed.), Handbook of Parenting. Volume 4: Social Conditions and Applied Parenting (2nd edition). Mahwah, NJ: Lawrence Erlbaum Associates, 149-80. 